\title{
QUALITY OF LIFE IN MOTHERS OF CHILDREN WITH CEREBRAL PALSY
}

\begin{abstract}
Alma Glinac ${ }^{1,2}$, Lejla Matović ${ }^{1}$, Azra Delalić ${ }^{1}$ and Lejla Mešalić ${ }^{3}$
${ }^{1}$ Tuzla University Clinical Center, Department of Physical Medicine and Rehabilitation; ${ }^{2}$ Faculty for Special Education and Rehabilitation, University of Tuzla;

${ }^{3}$ Dr Mustafa Šehović Public Health and Teaching Health Center, Tuzla, Bosnia and Herzegovina

SUMMARY - The aim of the study was to investigate whether there is difference in the quality of life between mothers of children with cerebral palsy and mothers of healthy children, as well as whether the quality of life in mothers of children with cerebral palsy depends on their level of education, child's mobility and child's functional status. A total of 141 mothers participated in the research. Mothers were divided into two groups, 71 mothers of children with cerebral palsy and 70 mothers of healthy children from the Tuzla Canton (Bosnia and Herzegovina). A multidimensional questionnaire PedsQL ${ }^{\mathrm{TM}}$ 2.0 Family Impact Mode was used for assessment of the impact of pediatric chronic health condition on the mothers' functioning. The level of functional disability of the child was measured by the Gross Motor Function Classification System (GMFCS levels I-V) scale. Mothers of children with cerebral palsy had poorer quality of life than mothers of healthy children in all investigated domains. In relation to mobility of the child, the quality of life was worse in mothers whose children did not move in the area of social functioning in comparison to mothers whose children had the ability to move independently. A statistically significant negative correlation existed between functional status of a child measured with GMFCS and social functioning of mothers, mothers' daily activities, parental functioning, family functioning, and overall quality of life of mothers.
\end{abstract}

Key words: Quality of life; Cerebral palsy; Mothers

\section{Introduction}

The quality of life is defined as the individual's perception of their own position in specific cultural, social and environmental context, as well as in relation to personal goals, expectations, standards and interests. It is a very broad term influenced by physical health and emotional status, as well as the level of individual's autonomy, their independence, social circumstances, personal beliefs and relations with the environment ${ }^{1}$. The quality of life connected with health is a subjective health condition or experience of health and refers to the impact of disease, damage, disorder, or in short of the health condition on the quality of life in order to be differentiated from other aspects of the quality of

Correspondence to: Alma Glinac, MS, Slatina 11, 75000 Tuzla, Bosnia and Herzegovina

E-mail: glinacalma@gmail.com

Received April 18, 2016, accepted November 3, 2016 life. It has a significant clinical interest in the case of family members involved in the treatment, especially in cases when patients are children ${ }^{2}$ because difficulties in the child's development require increased intensity of care, which may become a burden for parents and influence their physical and mental health ${ }^{3-8}$.

Cerebral palsy refers to a group of permanent disorders in the development of movement and posture, causing activity limitations, which are attributed to non-progressive disturbances that occurred in the developing fetal or infant brain. Motor disorders in cerebral palsy are often accompanied by disturbances of sensation, perception, cognition, communication and behavior, epilepsy or secondary musculoskeletal problems ${ }^{9}$. A child with cerebral palsy requires constant care, frequent medical examinations, continuous physical and educational-rehabilitation therapy and it affects the family dynamics ${ }^{10}$, especially mothers ${ }^{11}$, because they are the carriers of care, do most of the work 
related to the child, and spend most of the time with the child.

In this research, we were interested in the quality of life in mothers of children with cerebral palsy, the way they perceived the impact of their child's disease on their own life, and how much the presence of illness affected the functioning of the family according to their own report.

The general aim of the research was to examine whether there is difference in the quality of life between mothers of children with cerebral palsy and mothers of healthy children. The specific aims of the research were to find out:

- whether there is difference in the quality of life between mothers of children with cerebral palsy and mothers of healthy children in relation to their level of education,

- relationship between mobility of the child with cerebral palsy and the quality of life in mothers of children with cerebral palsy, and

- whether there is correlation between the quality of life in mothers of children with cerebral palsy and functional condition of the child.

\section{Subjects and Methods}

\section{Participants}

The study included 71 mothers of children with cerebral palsy who live in the Tuzla Canton (Bosnia and Herzegovina) and bring the child for examination or outpatient treatment to the Clinical Department of Physical Medicine and Rehabilitation, Tuzla University Clinical Center or to the Koraci nade (Steps of Hope) Center for Children with Multiple Disabilities in Tuzla. Control group consisted of 70 mothers of healthy children. Control group subjects were selected randomly and satisfied the following criteria: they have healthy children of the same age and gender as mothers from the experimental group and live in the Tuzla Canton.

All the participants filled in the questionnaire before (at home) or during the scheduled meeting. The research was conducted from the late 2012 till mid2015 . The criteria for participation in the research were as follows: mothers of children aged 5-18 and diagnosed with spastic form of cerebral palsy; children had not been diagnosed with some additional chronic dis- ease; mothers had not been diagnosed with some chronic or mental disease before the birth of the child; and living in the Tuzla Canton.

In relation to the ability of independent movement of the child, we divided mothers into two groups: mothers of children who can move independently (Gross Motor Function Classification System, GMFCS I, II and III) and mothers of children who cannot move independently (GMFCS IV and V). In relation to the level of education, mothers were divided into two groups: mothers with primary school and mothers with secondary school. The number of participants with higher educational degree was so small that they were excluded from the part of research that referred to examining the influence of education on functioning of mothers and family.

\section{Measuring instrument and procedure}

Assessment of the functioning condition of children with cerebral palsy was conducted using the GMFCS scale with five degrees of disability. The first and second degrees of disability (GMFCS I and II) include children who walk independently, with minimal restrictions outside the house and at greater distance. In third degree (GMFCS III) are children who use mobility aid (crutches, walkers) with significant restrictions outside the house and at greater distances. In fourth degree (GMFCS IV) are children who use wheelchairs to move, whereas fifth degree includes immobile children (GMFCS V) whose movement is restricted even with the help of a wheelchair because of their inability to control the head and torso while sitting.

The PedsQL ${ }^{\mathrm{TM}}$ 2.0 Family Impact Mode is a multidimensional instrument designed for assessment of the impact of pediatric chronic health conditions on the functioning of parents and family. It contains eight subscales with 36 questions, as follows: physical functioning (6 questions), emotional functioning (5 questions), social functioning (4 questions), cognitive functioning (5 questions), communication (3 questions), worries (5 questions), daily activities (3 questions), and family relations (5 questions). Problems that are covered in the area of physical functioning refer to the feeling of fatigue, headache, physical weakness and presence of stomachaches. The rest of the questionnaire covers the problems of emotional functioning (anxiety, sadness, anger, frustration, and helplessness or 
hopelessness); social functioning (the feeling of isolation, difficulties of receiving help from others, difficulties in finding time or energy for social activities); cognitive functioning (difficulties in the area of attention, memory and thinking); communication (the lack of understanding of situation in the family from others, difficulties of parents to talk about child's health condition with health professionals and other people); worries (worries about the effectiveness of treatment, side effects of drugs/medical therapy, concern how others will react to the child's condition, worries about the impact of child's illness on other family members, as well as worries about the child's future); daily activities (family activities take too much time and effort, difficulties in finding time to complete housework and feeling tired to finish the housework) and family relations (the lack of communication and conflicts among family members, difficulties in mutual decision-making and solving family issues, stress among family members) ${ }^{12}$.

In every area of the questionnaire, the question of how much problems a mother has in completing certain choirs has, as a result of the child's health, during the last month, is proposed and one answer is chosen. A 5-degree Likert scale was used, where 0 - never presents a problem, 1 - almost never presents a problem, 2 - sometimes presents a problem, 3 - often presents a problem, and $4-$ almost always presents a problem. On data processing, responses are scored in reverse and linear transformation into $0-100$ scale $(0=100,1=75,2=50,3=25,4=0)$ is performed, so that a greater number of scores presents better functioning (less negative impact). The overall rating is calculated as arithmetic mean of the responses ${ }^{13}$. Parental functioning is calculated as arithmetic mean of the responses of physical, emotional, social, cognitive functioning and worry, while family functioning is calculated as arithmetic mean of responses of daily activities and family relations.

The average time necessary for completion of these questionnaires is 10 to 15 minutes. Mothers completed the questionnaires individually, at home or in the presence of the researcher. Before examination, they were given brief oral instructions on completing the questionnaire, and, in accordance with the need, they were given additional help (reading questions aloud, interpretation of questions or explanation of words that respondents did not understand).
The questionnaire showed satisfactory metric characteristics. Its content and constructive validity and easy interpretability, sensitivity and reliability (Cronbach Alpha 0.90) were confirmed. Before using the PedsQL ${ }^{\text {TM }} 2.0$ survey, a contract was signed with the MAPI Research Institute from Lyon, France, an authorized institution for issuing a license for its use.

\section{Ethical aspect}

Mothers were informed on the importance of the requested data and by completing the questionnaire and signing it they gave their consent for the research.

\section{Statistical analysis}

Descriptive methods were applied in presenting basic demographic characteristics of the sample. In order to verify the normality of data, Shapiro Wilk test was applied, accepting $p>0.05$. Since data for the Ped$\mathrm{sQL}{ }^{\mathrm{TM}} 2.0$ survey did not follow normal distribution, nonparametric statistical tests were used. Differences between the groups of independent continuous variables were analyzed with Man-Whitney U-test for quantitative variables (assessment for the quality of life related to health). Results of the PedsQL ${ }^{\mathrm{TM}} 2.0$ survey were expressed as median and interquartile range ( $25^{\text {th }}-75^{\text {th }}$ percentile).

Spearman ( $r$ ) correlation of ranks was used for testing the association between the domains of PedsQL ${ }^{\mathrm{TM}}$ 2.0 instruments and GMFCS. A strong correlation was defined at $r>0.5$, moderate at $r \geq 0.3$, and mild, i.e. weak at $r<0.3$.

The value of $p<0.05$ was considered statistically significant. Data were analyzed using the Statistical Package for Social Sciences, Windows version 19.0.0.1 (SPSS Inc., Chicago, IL, USA).

\section{Results}

The median age of mothers of children with cerebral palsy was 36 years. Control group consisted of 70 mothers of healthy children, median age 36.5 years. Considering the level of education and marital status of mothers, there was no statistically significant difference between the groups, while a statistically significant difference was found in relation to employment (Table 1). Three mothers of children with cerebral palsy and eight mothers of healthy children had col- 
Table 1. Demographic data of study subjects

\begin{tabular}{|c|l|l|l|}
\hline \multirow{2}{*}{$\begin{array}{l}\text { Characteristic } \\
\text { of mothers }\end{array}$} & \multicolumn{2}{|c|}{ Subjects } & \\
\cline { 2 - 4 } & $\begin{array}{l}\text { Mothers of children } \\
\text { with cerebral palsy }\end{array}$ & $\begin{array}{l}\text { Mothers of healthy } \\
\text { children }\end{array}$ & $\mathrm{p}$ \\
\cline { 2 - 4 } & 71 & 70 & \\
\hline $\begin{array}{c}\text { Level of education: } \\
\text { primary }\end{array}$ & $\begin{array}{l}31.00(43.67 \%) \\
\text { secondary } \\
\text { college/university }\end{array}$ & $\begin{array}{l}14(20.00 \%) \\
48(68.00(52.10 \%)\end{array}$ & \multirow{2}{*}{$0.006^{*}$} \\
\hline $\begin{array}{c}\text { Employment: } \\
\text { employed }\end{array}$ & $10(14.08 \%)$ & $20(28.57 \%)$ & $0.003^{*}$ \\
unemployed & $61(85.92 \%)$ & $50(71.43 \%)$ & \\
\hline Marital status: & $68(95.77 \%)$ & $67(95.72 \%)$ & \\
married & $3(4.22 \%)$ & $3(4.28 \%)$ & $0.437^{* *}$ \\
\hline single & $36.00(34.00-42.00)$ & $36.50(33.00-41.25)$ & \\
\hline Median age (yrs) & & & \\
\hline
\end{tabular}

* $\chi^{2}$; **Man Whitney U-test

Table 2. Quality of life in mothers of children with cerebral palsy versus mothers of healthy children

\begin{tabular}{|c|c|c|c|c|c|}
\hline \multirow{2}{*}{$\begin{array}{l}\text { PedsQL }{ }^{\mathrm{TM}} \\
\text { Family Impact } \\
\text { Mode } 2.0\end{array}$} & \multirow{2}{*}{$\begin{array}{l}\text { No. } \\
\text { question }\end{array}$} & \multirow{2}{*}{$\begin{array}{l}\text { Mothers of children } \\
\text { with CP } \\
\text { (n=71) } \\
\text { Median (IQR) }\end{array}$} & \multirow{2}{*}{$\begin{array}{l}\text { Mothers of healthy } \\
\text { children } \\
\text { (n=70) } \\
\text { Median (IQR) }\end{array}$} & \multicolumn{2}{|c|}{ Mann-Whitney U } \\
\hline & & & & $z$ & $\mathrm{p}$ \\
\hline Physical functioning & 6 & $58.00(38.00-75.00)$ & $85.41(75.00-100.00)$ & -6.059 & $<0.0001$ \\
\hline Emotional functioning & 5 & $60.00(50.00-75.00)$ & $90.00(73.75-100.00)$ & -6.501 & $<0.0001$ \\
\hline Social functioning & 4 & $69.00(50.00-88.00)$ & $100.00(81.25-100.00)$ & -5.548 & $<0.0001$ \\
\hline Cognitive functioning & 5 & $80.00(60.00-100.00)$ & $100.00(85.00-100.00)$ & -4.164 & $<0.0001$ \\
\hline Communication & 3 & $67.00(42.00-83.00)$ & $100.00(83.33-100.00)$ & -7.243 & $<0.0001$ \\
\hline Worries & 5 & $50.00(30.00-65.00)$ & $85.00(60.00-100.00)$ & -6.567 & $<0.0001$ \\
\hline Daily activities & 3 & $42.00(17.00-67.00)$ & $83.33(56.24-100.00)$ & -6.382 & $<0.0001$ \\
\hline Family relations & 5 & $100.00(89.00-100.00)$ & $100.00(90.00-100.00)$ & -1.422 & 0.155 \\
\hline Parental functioning & 28 & $63.50(48.83-74.83)$ & $100.00(90.00-100.00)$ & -9.028 & $<0.0001$ \\
\hline Family functioning & 8 & $66.50(51.00-79.00)$ & $90.00(75.00-100.00)$ & -5.797 & $<0.0001$ \\
\hline Overall rating & 36 & $65.36(50.06-77.92)$ & $88.89(79.86-97.22)$ & -7.340 & $<0.0001$ \\
\hline
\end{tabular}

$\mathrm{CP}=$ cerebral palsy; $\mathrm{IQR}=$ interquartile range

lege/university degree. Due to the insufficient number of subjects in this group, data on college/university degree of education were not processed.

The majority of respondents in both groups were unemployed. The proportion of employed mothers was greater in control group than in the group of mothers of children with cerebral palsy (28.57\% vs. $14.08 \%)$. In the experimental group, $46 \%$ were mothers of daughters and $54 \%$ were mothers of sons, while in control group there were $67 \%$ of mothers of daughters and $33 \%$ of mothers of sons.

The median age of children with cerebral palsy and of healthy children was 9 and 8 years, respectively. In the group of children with cerebral palsy, 9 (12.68\%) 
Table 3. Quality of life in mothers of children with cerebral palsy versus mothers of healthy children according to the level of education

\begin{tabular}{|c|c|c|c|c|c|}
\hline \multirow[b]{2}{*}{$\begin{array}{l}\text { PedsQL }{ }^{\mathrm{TM}} \\
\text { Family Impact } \\
\text { Mode } 2.0\end{array}$} & \multirow[b]{2}{*}{ Subjects } & \multicolumn{2}{|c|}{ Years of education } & \multicolumn{2}{|c|}{ Mann Whitney U } \\
\hline & & \begin{tabular}{|l|} 
Primary education \\
Mothers of children \\
with CP ( $\mathrm{n}=31)$ \\
Mothers of healthy \\
children ( $\mathrm{n}=14)$ \\
Median (IQR)
\end{tabular} & $\begin{array}{l}\text { Secondary education } \\
\text { Mothers of children } \\
\text { with CP ( } \mathrm{n}=37) \\
\text { Mothers of healthy } \\
\text { children ( } \mathrm{n}=48) \\
\text { Median (IQR) }\end{array}$ & $z$ & $\mathrm{p}$ \\
\hline \multirow{2}{*}{$\begin{array}{l}\text { Physical } \\
\text { functioning }\end{array}$} & Mothers of children with CP & $54.00(38.00-71.00)$ & $58.00(35.50-87.50)$ & -0.432 & 0.666 \\
\hline & Mothers of healthy children & $85.41(73.95-100.00)$ & $83.33(75.00-98.95)$ & -0.376 & 0.707 \\
\hline \multirow{2}{*}{$\begin{array}{l}\text { Emotional } \\
\text { functioning }\end{array}$} & Mothers of children with $\mathrm{CP}$ & $55.00(45.00-70.00)$ & $61.00(50.00-75.00)$ & -1.039 & 0.299 \\
\hline & Mothers of healthy children & $100.00(70.00-100.00)$ & $90.00(71.25-100.00)$ & -1.064 & 0.287 \\
\hline \multirow{2}{*}{$\begin{array}{l}\text { Social } \\
\text { functioning }\end{array}$} & Mothers of children with CP & $69.00(50.00-81.00)$ & $69.00(44.00-94.00)$ & -0.558 & 0.577 \\
\hline & Mothers of healthy children & $100.00(85.93-100.00)$ & $100.00(81.25-100.00)$ & -0.310 & 0.757 \\
\hline \multirow{2}{*}{$\begin{array}{l}\text { Cognitive } \\
\text { functioning }\end{array}$} & Mothers of children with $\mathrm{CP}$ & $75.00(50.00-100.00)$ & $80.00(65.00-97.50)$ & -0.597 & 0.551 \\
\hline & Mothers of healthy children & $100.00(81.25-100.00)$ & $100.00(85.00-100.00)$ & -0.229 & 0.819 \\
\hline \multirow[t]{2}{*}{ Communication } & Mothers of children with $\mathrm{CP}$ & $67.00(42.00-83.00)$ & $65.00(42.00-87.50)$ & -0.366 & 0.715 \\
\hline & Mothers of healthy children & $95.83(83.33-100.00)$ & $100.00(91.67-100.00)$ & -1.371 & 0.170 \\
\hline \multirow[t]{2}{*}{ Worries } & Mothers of children with $\mathrm{CP}$ & $60.00(35.00-75.00)$ & $49.00(30.00-60.00)$ & -1.534 & 0.125 \\
\hline & Mothers of healthy children & $85.00(58.75-100.00)$ & $85.00(60.00-100.00)$ & -0.292 & 0.770 \\
\hline \multirow[t]{2}{*}{ Daily activities } & Mothers of children with $\mathrm{CP}$ & $33.00(17.00-58.00)$ & $42.00(12.50-63.00)$ & -0.600 & 0.548 \\
\hline & Mothers of healthy children & $100.00(95.83-100.00)$ & $75.00(80.00-100.00)$ & -2.873 & 0.004 \\
\hline \multirow[t]{2}{*}{ Family relations } & Mothers of children with $\mathrm{CP}$ & $100.00(95.00-100.00)$ & $90.00(70.00-100.00)$ & -2.729 & 0.006 \\
\hline & Mothers of healthy children & $100.00(100.00-100.00)$ & $100.00(90.00-100.00)$ & -1.907 & 0.057 \\
\hline \multirow{2}{*}{$\begin{array}{l}\text { Parental } \\
\text { functioning }\end{array}$} & Mothers of children with $\mathrm{CP}$ & $64.00(46.83-73.50)$ & $63.00(44.83-79.67)$ & -0.234 & 0.815 \\
\hline & Mothers of healthy children & $88.92(78.63-99.37)$ & $91.11(85.90-96.67)$ & -0.228 & 0.820 \\
\hline \multirow{2}{*}{$\begin{array}{l}\text { Family } \\
\text { functioning }\end{array}$} & Mothers of children with $\mathrm{CP}$ & $66.50(56.00-79.00)$ & $60.00(46.50-76.50)$ & -0.795 & 0.427 \\
\hline & Mothers of healthy children & $100.00(97.29-100.00)$ & $91.25(78.12-100.00)$ & -3.064 & 0.002 \\
\hline \multirow[t]{2}{*}{ Overall rating } & Mothers of children with $\mathrm{CP}$ & $64.00(50.06-75.06)$ & $65.36(49.65-79.28)$ & -0.129 & 0.897 \\
\hline & Mothers of healthy children & $90.97(81.07-99.48)$ & $87.50(77.77-95.65)$ & -0.902 & 0.367 \\
\hline
\end{tabular}

$\mathrm{CP}=$ cerebral palsy; $\mathrm{IQR}=$ interquartile range

children had been diagnosed with spastic hemiplegia, 38 (53.52\%) with spastic diplegia, and 24 (33.80\%) with spastic quadriplegia. According to the degree of functional disability as assessed with GMFCS, 28 (39.44\%) children with cerebral palsy had a certain form of independent movement, while 43 (60.56\%) children had no possibility of independent movement.

In all the areas tested except for family relations $(\mathrm{p}=0.155)$, mothers of children with cerebral palsy had poorer quality of life in comparison to mothers of healthy children. Mothers of children with cerebral palsy rated the quality of life in the area of communi- cation, worries, emotional functioning and daily activity as poorest (Table 2 ).

The quality of life related to health of mothers of children with cerebral palsy, according to their own report, was statistically significantly lower in the area of family relations in mothers with secondary education $(\mathrm{p}=0.006)$ than in mothers with primary education. Mothers of healthy children with secondary education, according to their own report, had a statistically significantly lower quality of life in the area of family functioning ( $p=0.002)$ than mothers with primary education who had healthy children (Table 3). 
Table 4. Quality of life in mothers of children with cerebral palsy according to movement of the child

\begin{tabular}{|c|c|c|c|c|c|}
\hline \multirow{2}{*}{$\begin{array}{l}\text { PedsQL } \\
\text { Family Impact Mode } 2.0\end{array}$} & \multirow{2}{*}{$\begin{array}{l}\text { No. } \\
\text { question }\end{array}$} & \multirow{2}{*}{$\begin{array}{l}\text { Moveable }(\mathrm{n}=28) \\
\text { Median (IQR) }\end{array}$} & \multirow{2}{*}{$\begin{array}{l}\text { Immovable }(\mathrm{n}=43) \\
\text { Median (IQR) }\end{array}$} & \multicolumn{2}{|c|}{ Mann-Whitney U } \\
\hline & & & & $\mathrm{z}$ & $p$ \\
\hline Physical functioning & 6 & $58.00(34.25-89.75)$ & $54.00(42.00-75.00)$ & -0.702 & 0.483 \\
\hline Emotional functioning & 5 & $67.50(50.00-75.00)$ & $55.00(40.00-70.00)$ & -1.388 & 0.165 \\
\hline Social functioning & 4 & $75.00(51.50-100.00)$ & $69.00(38.00-81.00)$ & -2.074 & 0.038 \\
\hline Cognitive functioning & 5 & $85.00(61.25-100.00)$ & $75.00(60.00-95.00)$ & -1.226 & 0.220 \\
\hline Communication & 3 & $67.00(44.00-98.00)$ & $67.00(42.00-83.00)$ & -0.432 & 0.666 \\
\hline Worries & 5 & $57.50(18.75-75.00)$ & $49.00(35.00-60.00)$ & -0.904 & 0.366 \\
\hline Daily activities & 3 & $50.00(25.00-79.00)$ & $42.00(8.00-58.00)$ & -1.685 & 0.092 \\
\hline Family relations & 5 & $100.00(90.00-100.00)$ & $95.00(85.00-100.00)$ & -0.980 & 0.327 \\
\hline Parental functioning & 28 & $69.42(48.87-80.08)$ & $63.00(46.83-73.00)$ & -1.418 & 0.156 \\
\hline Family functioning & 8 & $71.00(57.75-89.50)$ & $66.00(50.00-76.50)$ & -1.890 & 0.059 \\
\hline Overall rating & 36 & $72.87(53.66-83.13)$ & $64.00(48.72-75.06)$ & -1.630 & 0.103 \\
\hline
\end{tabular}

$\mathrm{IQR}=$ interquartile range

The quality of life in relation to the health of mothers of children with cerebral palsy whose children did not move, according to their own judgment, was statistically significantly $(\mathrm{p}=0.038)$ poorer in the area of social functioning than in the group of mothers whose children could move independently. In relation to mobility of the child, the quality of life of mothers, according to their own judgment, was not statistically significant in respect of the domains examined (Table 4).

There was a statistically significant negative correlation between functional status of the child measured with GMFCS and social functioning of mothers $(\mathrm{r}=$ -0.286 ; $\mathrm{p}<0.05)$, daily activities $(\mathrm{r}=-0.314 ; \mathrm{p}<0.01)$, $\mathrm{pa}^{-}$ rental functioning $(r=-0.255 ; \mathrm{p}<0.05)$, family functioning $(r=-0.327 ; p<0.01)$ and overall quality of life of mothers $(r=-0.270 ; p<0.01)$.

\section{Discussion}

Results of this research indicated that, according to their own report, the quality of life in mothers of children with cerebral palsy was statistically significantly poorer than in mothers of healthy children. The mothers assessed that they had the most evident difficulties in communication, worries, emotional functioning and daily activities. Previous studies showed that mothers of children with cerebral palsy ${ }^{14-17}$, as well as parents of chronically ill children ${ }^{18,19}$, had a lower quality of life in comparison to parents of healthy children. Mothers of children with difficulties had significantly more negative emotional conditions and more symptoms of de- pression ${ }^{14}$ because they had lack of positive feelings such as joy, pleasure, loveliness, pride and fulfillment of hope $^{20}$. It was found that over years, parents of children with cerebral palsy, in comparison to parents of healthy children, more often complained of experiencing severe and chronic stress, emotional and cognitive problems, as well as numerous somatic difficulties ${ }^{21-25}$. Mothers of children with cerebral palsy are exposed to psychological pressure, are under the impact of stress and depression, are worried for their child's future, most of their time spend on the child's nutrition, health, treatment, rehabilitation, are subjected to financial burdens (transport, child care, therapy, providing adaptive equipment and modifications in the house $)^{26}$, which causes decline in the quality of life of mothers (both physically and psychologically), whereas mothers of healthy children have more free time, are more involved in social activities, entertainment and work ${ }^{27}$. A significant factor that causes stress in parents is the lack of access to the existing possibilities of treatment and rehabilitation of children due to economic barriers. This leads to the feeling of incompletely executed parental obligations, guilt because of disability, fatigue, lack of rest, which often leads to conflict and crisis in the family ${ }^{28}$. Chronic illness of a child, in terms of quality of life, affects family and parents more than the child ${ }^{29}$, because restrictions in the child's independence cause greater burden on the parents ${ }^{30}$. Contrary to the results of our study, in the study by Okurowska et al. half of the parents of children with cerebral palsy described their quality of life and health as good ${ }^{31}$. 
Table 5. Correlation of five dimensions of health measured with Peds $Q L^{T M}$ 2.0, parental functioning, family functioning, overall ratings and GMFCS

\begin{tabular}{|c|c|c|c|c|c|c|c|c|c|c|c|}
\hline $\begin{array}{l}\text { PedsQL }{ }^{\mathrm{TM}} \\
\text { Family } \\
\text { Impact } \\
\text { Mode } 2.0\end{array}$ & 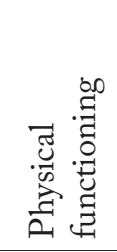 & 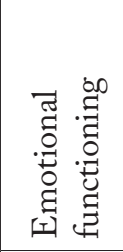 & 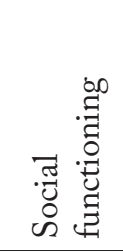 & 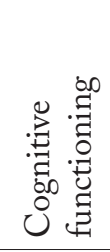 & 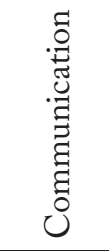 & $\frac{\mathscr{s}}{\mathscr{E}}$ & 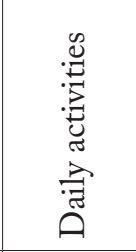 & 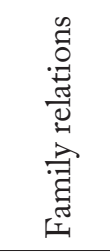 & 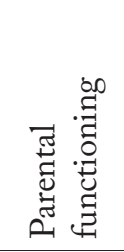 & 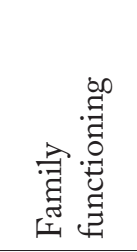 & 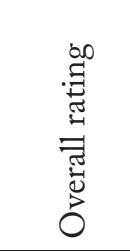 \\
\hline GMFCS & -0.124 & -0.209 & $-0.286^{*}$ & -0.214 & -0.150 & -0.185 & $-0.314^{* *}$ & -0.096 & $-0.255^{*}$ & $-0.327^{* *}$ & $-0.270^{* *}$ \\
\hline
\end{tabular}

*significant at $\mathrm{p}<0.05 ;$ **significant at $\mathrm{p}<0.01 ;$ GMFCS $=$ Gross Motor Function Classification System

According to the results of our study, mothers of children with cerebral palsy, who had secondary education, had a statistically significantly poorer quality of life only in the area of family relations $(p=0.006)$ in comparison to mothers of children with cerebral palsy who had primary education. Bumin et al. ${ }^{10}$ and Erdoğanoğlu and Günel ${ }^{32}$ report opposite results, indicating that the quality of life in mothers of children with cerebral palsy depends on the level of education.

According to the child's ability to move, the quality of life related to the health of mothers of children with cerebral palsy whose children did not move, according to their own judgment, was statistically significantly worse ( $\mathrm{p}=0.038$ ) only in the area of social functioning, in comparison to the group of mothers whose children had the ability to move independently. Keller and Honig also indicate that disability in children reduces social activity of the mother ${ }^{33}$.

There was a statistically significantly negative correlation between functional condition of the child measured with GMFCS and social functioning of mothers $(\mathrm{r}=-0.286 ; \mathrm{p}<0.05)$, daily activity $(\mathrm{r}=-0.314$; $p<0.01)$, parental functioning $(r=-0.255 ; \mathrm{p}<0.05)$, family functioning $(r=-0.327 ; \mathrm{p}<0.01)$ and overall quality of life of mothers $(r=-0.270 ; p<0.01)$. Research on the impact of functional condition of the child with cerebral palsy on the quality of life of mothers failed to show uniform results. On the one hand, there are authors who emphasize connection ${ }^{32,34}$, whereas on the other hand, there are those who emphasize that there is no connection ${ }^{17}$.

\section{Conclusion}

The results of our study yielded statistically significant differences between the quality of life in mothers of children with cerebral palsy in comparison to mothers of healthy children. When planning the program of rehabilitation of children with cerebral palsy, it is also necessary to assess the quality of life of mothers who have the most significant role in the process of care and rehabilitation of the child. Proper functioning of mothers and family increases the possibility of creating conditions necessary for optimal development of the child.

\section{References}

1. The WHOQOL Group. Development of the World Health Organization WHOQOL-BREF quality of life assessment. Psychol Med. 1998;28(3):551-8. http://dx.doi.org/10.1017/ s0033291798006667

2. Rudolph M, Kummer P, Eysholdt U, Rosanowski F. Quality of life in mothers of speech impaired children. Logoped Phonatr Vocol. 2005;30(1):3-8. http://dx.doi.org/10.1080/140154304 10022292

3. Fonseca A, Nazaré B, Canavarro MC. Parental psychological distress and quality of life after a prenatal or postnatal diagnosis of congenital anomaly: a controlled comparison study with parents of healthy infants. Disabil Health J. 2012;5(2):67-74. http://dx.doi.org/10.1016/j.dhjo.2011.11.001

4. Uskun E, Gundogar D. The levels of stress, depression and anxiety of parents of disabled children in Turkey. Disabil Rehabil. 2010;32(23):1917-27. http://dx.doi.org/10.3109/0963828 1003763804

5. Benjak T, Vuletić Mavrinac G, Pavić Šimetin I. Comparative study on selfperceived health of parents of children with autism pectrum disorders and parents of nondisabled children in Croatia. Croat Med J. 2009;50(4):403-9. http://dx.doi.org/ 10.3325/cmj.2009.50.403

6. Glenn S, Cunningham C, Poole H, Reeves D, Weindling M. Maternal parenting stress and its correlates in families with a young child with cerebral palsy. Child Care Health Dev. 2009;35(1):71-8. http://dx.doi.org/10.1111/j.1365-2214.2008. 00891.x

7. Maes B, Broekman TG, Došen A, Nauts J. Caregiving burden of families looking after persons with intellectual disability and behavioural or psychiatric problems. J Intellect Disabil 
Res. 2003;47(6):447-55. http://dx.doi.org/10.1046/j.1365-27 88.2003.00513.x

8. Glasscock R. A phenomenological study of the experience of being a mother of a child with cerebral palsy. Pediatr Nurs. 2000;26(4):407-10. http://dx.doi.org/10.3109/17483107.2012 .692172 .

9. Rosenbaum P, Paneth N, Leviton A, Goldstein M, Bax M, Damiano D, Jacobsson, B. A report: the definition and classification of cerebral palsy April 2006. Dev Med Child Neurol Suppl. 2007;109 (Suppl 109):8-14. http://dx.doi.org/10.1111/ j.1469-8749.2007.tb12610.x

10. Bumin G, Günal A, Tükel Ş. Anxiety, depression and quality of life in mothers of disabled children. Med J SDU. 2008;15(1): 6-11.

11. Hastings RP, Kovshoff H, Brown T, Ward NJ, Degli Espinosa F, Remington B. Coping strategies in mothers and fathers of preschool and school-age children with autism. Autism. 2005; 9(4):377-91. http://dx.doi.org/10.1177/1362361305056078

12. Varni JW, Sherman SA, Burwinkle TM, Dickinson PE, Dixon P. The PedsQL ${ }^{\text {тм }}$ family impact module: preliminary reliability and validity. Health Qual Life Outcomes. 2004;2(1):55. http:// dx.doi.org/10.1186/1477-7525-2-55

13. Varni JW, Limbers CA, Burwinkle TM. Impaired health-related quality of life in children and adolescents with chronic conditions: a comparative analysis of 10 disease clusters and 33 disease categories/severities utilizing the PedsQL ${ }^{\mathrm{TM}} 4.0 \mathrm{Ge}^{-}$ neric Core Scales. Health Qual Life Outcomes. 2007;5(1):43. http://dx.doi.org/10.1186/1477-7525-5-43

14. Diwan DS, Chovatiya DH, Diwan DJ. Depression and quality of life in mothers of children with cerebral palsy. Natl J Integr Res Med. 2011;2(4):11-3.

15. Davis E, Shelly A, Waters E, Boyd R, Cook K, Davern M. The impact of caring for a child with cerebral palsy: quality of life for mothers and fathers. Child Care Health Dev. 2010;36(1): 63-73. http://dx.doi.org/10.1111/j.1365-2214.2009.00989.x

16. Lim Y, Seer M, Wong CP. Impact of cerebral palsy on the quality of life in patients and their families. Neurol Asia. 2009; 14(1):27-33.

17. Eker L, Tüzün EH. (2004). An evaluation of quality of life of mothers of children with cerebral palsy. Disabil Rehabil. 2004;26(23):1354-9. http://dx.doi.org/10.1080/09638280400 000187

18. Farnik M, Brozek G, Pierzchala W, Zejda JE, Skrzypek M, Walczak L. Development, evaluation and validation of a new instrument for measurement quality of life in the parents of children with chronic disease. Health Qual Life Outcomes. 2010;8(9):151. http://dx.doi.org/10.1186/1477-7525-8-151

19. Khayatzadeh M. A comparative study about quality of life in mothers of children with cerebral palsy, mental retardation and mothers of normal children. Daneshvar Med J. 2009;16(83): 49-58.

20. Veisson M. Depression symptoms and emotional states in parents of disabled and non-disabled children. Soc Behav Personal. 1999;27(1):87-97. http://dx.doi.org/10.2224/sbp.1999.27.1.87
21. Brehaut JC, Kohen DE, Raina P, Walter SD, Russell DJ, Swinton M, Rosenbaum P. The health of primary caregivers of children with cerebral palsy: how does it compare with that of other Canadian caregivers? Pediatrics. 2004;114(2):e182-e191. http://dx.doi.org/10.1542/peds.114.2.e182

22. Romeo DM, Cioni M, Distefano A, Battaglia LR, Costanzo L, Ricci D, Sanctis RD, Romeo MG, Mazzone D, Mercuri E. Quality of life in parents of children with cerebral palsy: is it influenced by the child's behaviour? Neuropediatrics. 2010; 41(3):121-6. http://dx.doi.org/10.1055/s-0030-1262841

23. Garel M, Dardennes M, Blondel B. Mothers' psychological distress 1 year after very preterm childbirth. Results of the EPIPAGE qualitative study. Child Care Health Dev. 2006;33(2): 137-43. http://dx.doi.org/10.1111/j.1365-2214.2006.00663.x

24. Kaya K, Unsal-Delialioglu S, Ordu-Gokkaya NK, Ozisler Z, Ergun N, Ozel S, Ucan H. Musculo-skeletal pain, quality of life and depression in mothers of children with cerebral palsy. Disabil Rehabil. 2010;32(20):1666-72. http://dx.doi.org/10. 3109/09638281003649912

25. Yilmaz H, Erkin G, İzki AA. Quality of life in mothers of children with cerebral palsy. ISRN Rehabilitation, 2013. http:// dx.doi.org/10.1155/2013/914738

26. Almasri NA, Palisano RJ, Dunst CJ, Chiarello LA, O’Neil ME, Polansky M. Determinants of needs of families of children and youth with cerebral palsy. Child Health Care. 2011;40(2):130-54. http://dx.doi.org/10.1080/02739615.2011 .564568

27. Borzoo S, Nickbakht M, Jalalian M. Effect of child's cerebral palsy on the mother: a case control study in Ahvaz, Iran. Acta Fac Med Naiss. 2014;31(1):75-9. http://dx.doi.org/10.2478/ afmnai-2014-0008

28. Sendecka E, Wiśniewska E, Krajewska-Kułak E, Kułak W. Funkcjonowanie społeczne rodziny z dzieckiem niepełnosprawnym. Neurol Dziec. 2010;19(37):67-75. (in Polish)

29. Eiser C, Morse R. Quality-of-life measures in chronic diseases of childhood. Health Technol Assess. 2001;5(4):1-157. http:// dx.doi.org/10.3310/hta5040

30. Parchomiuk M. Rodzice dzieci z mózgowym porażeniem dziecięcym wobec sytuacji trudnych. Wydawnictwo Uniwersytetu Marii Curie-Skłodowskiej; 2007. (in Polish)

31. Okurowska ZB, Kułak W, Wojtkowski J, Sienkiewicz D, Paszko PG. Quality of life of parents of children with cerebral palsy. Progr Health Sci. 2011;1(1):116-23.

32. Erdoğanoğlu Y, Günel MK. Serebral paralizili çocukların ailelerinin sağlıkla ilgili yaşam kalitelerinin araştırılması. Toplum Hekimliği Bülteni. 2007;26(2):35-9. (in Turkish)

33. Keller D, Honig AS. Maternal and paternal stress in families with school-aged children with disabilities. Am J Orthopsychiatry. 2004;74(3):337-48. http://dx.doi.org/10.1037/00029432.74.3.337

34. Tuna H, Ünalan H, Tuna F, Kokino S. Quality of life of primary caregivers of children with cerebral palsy: a controlled study with Short Form-36 questionnaire. Dev Med Child Neurol. 2004;46(09):647-8. http://dx.doi.org/10.1111/j.1469-8749.2004.tb01031.x 
Sažetak

\section{KVALITETA ŽIVOTA MAJKI DJECE S CEREBRALNOM PARALIZOM}

\section{A. Glinac, L. Matović, A. Delalić i L. Mešalić}

Cilj ovoga istraživanja bio je ispitati postoji li razlika u kvaliteti života između majki djece s cerebralnom paralizom i majki zdrave djece te ovisi li kvaliteta života majki djece s cerebralnom paralizom o stupnju obrazovanja majki, pokretljivosti djeteta i funkcionalnom statusu djeteta. $U$ istraživanju je sudjelovala ukupno 141 majka. Majke su bile podijeljene u dvije skupine: 71 majka djece s cerebralnom paralizom i 70 majki zdrave djece s područja Tuzlanskog kantona (BiH). Za procjenu utjecaja pedijatrijskih kroničnih zdravstvenih stanja na funkcioniranje majki korišten je višedimenzionalni upitnik $P e d s Q L^{T M}$ 2.0 Family Impact Mode. Stupanj funkcionalne onesposobljenosti djeteta procijenjen je primjenom ljestvice Gross Motor Function Classification System (GMFCS razine I.-V.). Majke djece s cerebralnom paralizom su imale lošiju kvalitetu života u usporedbi s majkama zdrave djece u svim ispitivanim domenama. U odnosu na pokretljivost djeteta kvaliteta života bila je lošija kod majki čija se djeca ne kreću, u području društvenog funkcioniranja, u odnosu na majke čija djeca imaju sposobnost neovisnog kretanja. Statistički značajna negativna povezanost je postojala između funkcionalnog statusa djeteta mjerenog GMFCS i društvenog funkcioniranja majki, dnevnih aktivnosti majki, roditeljskog funkcioniranja, obiteljskog funkcioniranja i ukupne kvalitete života majki.

Ključne riječi: Kvaliteta života; Cerebralna paraliza; Majke 